\title{
THE INTERDISCIPLINARITY OF THE SCIENTIFIC RESEARCH OF LAW. THE INSOLVENCY INSTITUTION - AN INTEGRATIVE AREA CONFIGURED AND RESIZED BY THE INTERSECTION OF THE LEGAL, ECONOMIC AND SOCIAL REALITIES
}

\section{Didea, D.-M. Ilie, R.D. Vidican}

\section{PhD Professor Ionel Didea}

Faculty of Economics and Law, University of Pitești, Romania

Faculty of Law-Doctoral School

"Titu Maiorescu" University, Bucharest, Romania

*Correspondence: Ionel Didea, University of Piteşti, str. Târgu din Vale, no. 1, Pitești, Romania

E-mail: prof.didea@yahoo.com

\section{PhD Student Diana Maria Ilie}

Legal and Human Resources Department, University of Pitești, Romania

Doctoral School-Law Field

"TituMaiorescu" University, Bucharest, Romania

*Correspondence: Diana Maria Ilie, University of Pitești, str. Târgu din Vale,

nr. 1, Pitești, Romania

E-mail: dianamaria.ilie@yahoo.com

\section{PhD Student Roxana-DenisaVidican}

Faculty of Legal and Administrative Sciences,

Agora University of Oradea, Romania

Doctoral School-Law Field

"Titu Maiorescu" University, Bucharest, Romania

*Correspondence: Roxana-Denisa Vidican, Agora University of Oradea, Piaţa Tineretului no.

8, Oradea, Romania

E-mail: vidican.roxana@yahoo.com

\begin{abstract}
Law is a dynamic social phenomenon reconfigured and re-dimensioned by the continuous and complex changes of the society, the multidisciplinary and especially the interdisciplinary of scientific research ensuring the dynamics of the norms of law outlined in the light of an integrative knowledge so necessary in the postmodern era.
\end{abstract}

KEYWORDS: interdisciplinary, transdisciplinary, insolvency, innovation, research, economic context, social context.

\section{INTRODUCTION.}

The need for excellence in research requires an interdisciplinary, multidisciplinary and transdisciplinary analysis of sciences in general, the disciplinary research being characterized by "scientific rigidness". The interdisciplinary approach stimulates innovation, creativity. The capacity of analyzing and connecting concepts and ideas from different and even contrasting perspectives, thus developing new research areas, which correspond to certain current social, economic and political interests.

The traditional branches of law are gradually reconfigured, oscillating between fragmentation and fusion, phenomena that lead to the emergence of other disciplines, fields, 
legal institutions, as a result of the continuous changes of the society, unavoidably creating bridges that ling the legal sciences and the auxiliary sciences through connections, transfers of concepts, ideas, analysis methods and techniques, interrelations, interferences, required by the exigencies of the legal approach in outlining the set of legal norms which nevertheless keep their identity.

Insolvency remains a controversial and topical subject that provides a wide spectrum of analysis, even in an interdisciplinary manner, representing a real interest in the current and future socioeconomic environment, and also an expanded interest in the international context (cross-border insolvency). Insolvency law can be considered a result of the approach of the research and of the interdisciplinary analysis in the context of the branches pertaining to the field of economy, sociology, psychology, but also of the branches of law, through its interference with other domestic and international normative acts, such as labor law regulations, criminal law, civil law, civil procedural law, administrative law, public procurement, etc., which have left their mark on the evolution of insolvency and have created new analysis perspectives, new legal visualizations, outlining, why not, a special, particular, individual law, insolvency law, which crossed the limits of commercial law and expanded to natural persons and to administrative and territorial units.

\section{BRIEF CONSIDERATIONS. INTERDISCIPLINARITY - A "SINE QUA NON" PREREQUISITE OF SCIENTIFIC RESEARCH}

The multidisciplinary, interdisciplinary and transdisciplinary research approach, provides an overall perspective of the legal phenomena, which allows for the interconnection of the realities, needs and expectations of the society in general, boosting, synthesizing and ensuring, at the same time, the profoundness of the regulations with legal content. The social and economic realities continuously configure the normative form, requiring a multiplication of the perspectives, which since it is many times imperceptible, generates a slow or a sudden transformation of the legal content, by fragmentations of law branches, or fusions of these branches, the separation of certain legal institutions which gradually substantiate their status of law branches based on their own principles, procedures and resources for the exclusion and filtration of the rules coming from outside which are specific to other law branches.

The origins of the interdisciplinary policy can be found in the 1920s, in the United States of America, when the Social Science Research Council was established, in order to promote research concerning several disciplines. Interdisciplinary programs were initially used in the USA, being taken over by Great Britain and expanded as bachelor's and master's specialties, later initiated in the entire European community. ${ }^{1}$ National Science Teachers Association (NSTA) established in the United States of America also played an important role in promoting interdisciplinarity, because it developed, in 1964 a list of fundamental concepts common to sciences, in order to expand the curricula. ${ }^{2}$ At the same time, UNESCO played an essential role in the promotion and highlighting of the interdisciplinarity principle, initiating, at the beginning of the seventh decade, projects based on integrated sciences.

An important episode in the promotion of interdisciplinarity was the report published in 1972 by the Centre for Educational Research and Innovation (CERI), a structure of the Organization for Economic Cooperation and Development (OECD), which report initiated a joint international effort in this direction, promoting the idea of keeping the disciplinary identity, without rejecting, however, certain forms of conceptual and methodological

\footnotetext{
${ }^{1}$ V. Cojanu, Interdisciplinaritatea în științele sociale ca problemă de management, in Revista de Politica Științei și Scientometrie - New series, Vol. 3, No. 1, INOE, Măgurele, 2014, pp. 31 and subsequent.

${ }^{2}$ A. Jula, Interdisciplinaritatea și transdisciplinaritatea, factori de creștere a calității învățământului universitar - http://www.agir.ro/buletine/83.pdf.
} 
integration, by approaching the following definition: "Interdisciplinarity - an adjective describing the interaction among two or more different disciplines. This interaction may range from simple communication of ideas to the mutual integration of organizing concepts, methodologies, procedures, epistemology, terminology, data and organization of research and education in a fairly large field. An interdisciplinary group consists of persons trained in different fields of knowledge (disciplines), with different concepts, methods and data and terms organized into a common effort on a common problem with continuous intercommunication among the participants from the different disciplines." 3

Under the aegis of OECD, very many international conferences were organized in relation to the advantages and disadvantages of the interdisciplinary research, and work seminars took place in prestigious universities, activities that gradually led to the outlining and development of the interdisciplinarity principle, the interdisciplinarity route characterizing the top of modern science and the revival of the educational system. ${ }^{4}$ Moreover, disciplines interact in time and space, generating new disciplines, branches and fields of knowledge that imply numerous social, economic, technological, ecological, political, and legislative factors, etc. The interest in promoting the approach of interdisciplinary education and research has been enhanced by establishing institutions, organizations such as Association for Integrative Studies - AIS, International Association for the Study of Interdisciplinary Research INTERSTUDY, Center for the Study of Higher Education, etc., comprising members coming from the government, industry, business area, specialists in various fields co-opted in universities, which focused on the consolidation of the methodology, interdisciplinary research strategies, and on the approach of an interdisciplinary curricula in the educational system. Following practical experiments, it was determined that in the educational system, an interdisciplinary approach captures students' interest and helps them, at the same time, to connect information, from a multitude of perspectives, developing high analysis capacities, both overall, complex, as well as synthesis ones, forming critical thinking, tolerance for ambiguity and acceptance of innovation, by creating new horizons and bridges between various disciplines, borrowing and crossing methods and concepts, thus stimulating an original manner of thinking. ${ }^{5} \mathrm{~A}$ number of such experiments ${ }^{6}$ highlighted the importance and the role of interdisciplinarity in the evolution of society in general, a concept that underwent changes in the approach and definition, over time, due to the fact that a "fight" between specialization and integration continued to exist. As Hans Klette said ${ }^{7}$ in an international conference held in 1975, the society continues to oscillate between unity and diversity, between cooperation and isolation, between concrete research and abstract research. Thus, we ask ourselves the following question: is interdisciplinarity a philosophical or a practical concept? We can certainly say that interdisciplinarity is a practical concept, not only an aspect approached from the philosophical point of view, because it has marked the education and research system in a concrete, tangible manner. We cannot deny that man is by nature a complex being who evolves in a more complex world, which requires an overall, integrative perspective and also capacity of synthesis, in order to adjust and reach a balance between the needs of the human being, the society viewed as a whole with the specific economic,

\footnotetext{
${ }^{3}$ OECD, Interdisciplinarity: Problems of Teaching and Research in Universities, Paris, OECD, 1972 - apud C. Toth, Raport privind cercetarea interdisciplinară, DOCSOC - Excelență, inovație și interdisciplinaritate în studiile doctorale și postdoctorale în sociologie -

- http://docsoc.sas.unibuc.ro/wp-content/uploads/2013/09/DOCSOC_E2_Raport-cercetare-interdisciplinara.pdf

${ }^{4}$ Julie Thompson Klein, Interdisciplinarity: History, Theory and Practice, Wayne State University Press, Michigan, 1990, p. 36 and subsequent.

${ }^{5}$ Lisa R. Lattuca, L.J. Voight, K.Q. Fath, Does Interdisciplinarity Promote Learning? Theoretical Support and Researchable Questions, The Review of Higher Education, Fall 2004, Volume 28, pp.23-48.

${ }^{6}$ See Casey Jones, Interdisciplinary Approach - Advantages, Disadvantages, and the Future Benefits of Interdisciplinary Studies, ESSAI, Volume 7, 2010

- http://dc.cod.edu/cgi/viewcontent.cgi? article $=1121 \&$ context $=$ essai

7 Julie Thompson Klein, op. cit., p. 38.
} 


\section{THE INTERDISCIPLINARITY OF THE SCIENTIFIC RESEARCH OF LAW. THE \\ INSOLVENCY INSTITUTION - AN INTEGRATIVE AREA CONFIGURED AND RESIZED \\ BY THE INTERSECTION OF THE LEGAL, ECONOMIC AND SOCIAL REALITIES}

legislative, social, political administrative implications, but also the implications of the environment characterized by its own universal laws. This is precisely why we talk about a rigorous knowledge path, more specifically, the deepening of disciplinary, segmented type, in order to understand the essence, subsequently following the multidisciplinary, pluridisciplinary approach, of juxtaposing information, and the interdisciplinary one, respectively, which provides the integrative, synthesizing vision, to transdisciplinarity, which involves crossing the disciplinary borders and the capacity to work with new concepts, theories and methodologies that are not actually specific to a single discipline or branch. This high level of knowledge allows, in fact, for the possibility to give a favorable answer to the so complex global challenges. In the spirit of the promotion of transdisciplinarity, the Centre International de Recherces et d'Etudes Transdisciplinaires - CIRET, was established, which develops, in collaboration with UNESCO "The Transdisciplinary Evolution of the University", a project discussed in the International Conference "Which University for Tomorrow?" held in 1997, proposing an educational system that should allocate time for the transdisciplinary approach by creating transdisciplinary research workshops and preparing $\mathrm{PhD}$ theses in this respect. ${ }^{8}$

Interdisciplinarity remains a controversial field, practically understood and applied in various and surprising ways, a field of interest still present in the studies and research of the great international bodies, which promote an integrative vision, exceeding the traditional borders of the disciplinary approach. Thus, on the website of the Organization for Economic Cooperation and Development, we identify research programs, projects, reports and activities proposed for the promotion of the interdisciplinary science and innovation, as perspectives that are so necessary in the context of global changes, such as for example health and climate. ${ }^{9}$ In fact, the real concern and interest for the promotion of interdisciplinarity can also be inferred from the project consecrated in this respect, namely: "An interdisciplinary perspective on 2020 Science" 10 , outlining the idea of the need to train scientists in wide scientific areas and branches. Moreover, this is also invoked as a measure required as a matter of urgency ${ }^{11}$, due to the current concern to understand the functionality, survival of the planet in general, viewed and analyzed by integrating several scientific perspectives, a "computer of science" type of integration that allows for a functional analytic and strategic system which provides an integrative vision corresponding to the needs of humankind and society, in perfect balance with nature, the ecologic, biologic system, based on an equal and correct distribution of the resources, the predictions related to disasters, global catastrophes as a result of human activity being already known ("Science 2020 presents the world as seen from a computerscience + biological sciences viewpoint. What could the integration of other viewpoints contribute?"). Thus, we are dealing with new research areas, such as the ecological economy, biotechnology, globalization, artificial intelligence, digital technology, etc., fields that were also included in the plan of debates, studies and recommendations of the Organization for Economic Cooperation and Development, the changes and perspectives of the $21^{\text {st }}$ century being marked by the speed of global transformations that require an integrative research and approach vision. Moreover, the implementation of such strategic plans is an opportunity for significant innovation and evolution of any country, and such plans can be accessed by adhesion. Romania's adhesion to OECD is a strategic objective of the Romanian foreign policy, included in the current governance plan, and Romania officially applied for the adhesion to OECD during the previous enlargement exercises, more specifically in April 2004

\footnotetext{
${ }^{8}$ Basarab Nicolescu is one of the most well-known Romanian researchers in the transdisciplinarity field - B. Nicolescu, "The Transdisciplinary Evolution of the University"

- http://cds.cern.ch/record/365269/files/SCAN-9809055.pdf

${ }^{9}$ http://www.oecd.org/sti/inno/measuringinnovationanewperspective.htm

${ }^{10} \mathrm{http}: / /$ www.oecd.org/innovation/research/37592129.pdf

11 "There is a fundamentally urgent need to understand the Earth's life support systems..."
} 
and November 2012, and renewed it in 2016 and in 2017. The main advantages of Romania's potential adhesion to OECD would be: the benefit of Romania's belonging to the restricted club of developed economies and the implicit recognition, at global level, of its status of functional market economy and consolidated democracy, with an impact on the country's rating and on the attraction of foreign investments; the benefit of the example, Romania's favorable image both in relation to the big economies of the world (USA, China, Japan, etc.), and in relation to the countries in the region with European aspirations (Moldova, Macedonia, Albania, Serbia, etc.); the benefit of expertize, the access to the information required in the priority areas for Romania (governance framework, legislative reform, anti-corruption, tax policy, transport infrastructure, agriculture, education, etc.); the benefit of Romania's access to economic decision instruments and centers of OCDE and the possibility to contribute to the global economic governance; the benefit of assistance in relation to public policies from OCDE members by periodical assessment of Romania's policies in specific areas (peer reviews) and issuing recommendations for their improvement. ${ }^{12}$

By outlining an overall image of interdisciplinarity, with all its implications, we understand why it is a current challenge, an approach that can be found not only in theory, but also at practical level in the future strategy of any structure, organization, society, government, state, etc.

Returning to scientific research, we consider that it is imperative to exceed the traditional boundaries of disciplines and to implement an educational system focused on the interdisciplinary study, especially in the higher education system, which is the key point of the development strategy of a society able to respond to unavoidable global challenges, by training people able to make inter-connections that should further develop and apply these aspects. Romanian universities can follow the example of great education institutions in the developed states such as Great Britain, namely to attract research funds through competition, dedicated to the construction of transdisciplinary consortiums, comprising specialists from various fields, in order to respond to global challenges such as climate, infectious diseases, pollution, virus spread, mass industrialization, etc. The interdisciplinary approach is practiced in our country especially in our doctoral and postdoctoral programs. It would bode well, however, that the national education law regulate the possibility of creating interdisciplinary work departments, in which students specialized in different disciplines, fields, could carry out debates, researches, applying various methodologies from the sociological, economic, legislative perspective, etc., around the same subject of interest, in a current and real context, developing conceptual "bridge" between disciplines and responding to the challenges of the $21^{\text {st }}$ century. Moreover, the current diverse demands of our society have prompted young people's interest in multidisciplinary training, such young people graduating from two or three faculties in different fields.

Strictosensu, the interdisciplinary nature of the scientific research of law, a field of interest in the present study, creates a multiplication of perspectives, resulting in the fragmentation of the branches of law, cohesions with other sciences, the configuration of new institutions of law, new branches, ensuring the complex research of juridical phenomena in the attempt to develop an all-encompassing juridical order able to adapt to the dynamics of the social, economic, administrative, environmental, health realities, etc., which are triggering factors of the juridical mechanism.

\footnotetext{
${ }^{12}$ https://www.mae.ro/node/18539
} 


\section{THE CONTINUOUS RESIZING OF LAW THROUGH COHESIONS WITH OTHER SCIENCES AND CONNECTIONS WITH THE ECONOMIC, SOCIAL AND POLITICAL REALITIES AND TRENDS. BETWEEN THE TENDENCY TO FRAGMENT LAW AND THE ASPIRATION TOWARDS UNITY}

Law is a dynamic phenomenon, configured and resized by the social, historical, cultural, moral, political and economic context, a phenomenon that has gradually abandoned the autonomous, closed system hypostasis and has inevitably turned towards an open, flexible, integrative, interdisciplinary, complex system, which are, as a matter of fact, specific characteristics of our century, a century of complexity. This vision matches the effective reality, complexity being "a state of the natural, social, human world". ${ }^{13}$

Consequently, law cannot escape interferences, requiring a multitude of perspectives, such as the philosophical perspective in response to the necessity of deepening and knowing the human condition, the sociological perspective, due to the fact that law reflects the social needs and the moral condition of the society in general, the political perspective, the administrative and political system influencing the law system, outlined in a democratic state that promotes the principle of the separation of powers in the state, democratic values, rights and liberties, as law is a phenomenon that successfully preserves its specificity and autonomy and that can be invaded at the same time by multidimensional realities, which outline the juridical norm filled with social, political, philosophical, moral, cultural contents, legal actors, such as the legislator, the prosecutor, the judge, etc., playing an essential role in its concrete application in a given context.

We invoke the autonomy and the specificity of law precisely in the idea of preserving the moral values on which it was founded and on the basis of which it develops and cannot be transformed into a mere instrument subordinated to the political or economic interests, the juridical phenomenon tending in its evolution towards a "moral ideal". ${ }^{14}$

In its evolution, law oscillated between fragmentation and unity, the tendency of fragmentation ensuring the depth of legal interpretation, but also the multiplication of perspectives, the "birth" of transcendent matter through the cohesion of law with other sciences. Law has been explored in all its hypostases, starting from the fundamental division, public-private law, the traditional division of the legal systems that remains topical, following the ramification under the pressure of the aforementioned external factors. Thus, the legal regulations have expanded and continue to expand in the most diverse areas of life, constituting branches of legal sciences, such as civil law, commercial law, criminal law, administrative law, constitutional law, etc., branches that were fragmented, in their turn, into institutions of law (Special Contracts, Principal Real Rights, Obligations, Administrative Act, Insolvency, etc.), legal orders, the fragmentation still producing other smaller "legal pieces of analysis"15, individually studied and deepened. Moreover, around this normative flow that is so complex, integrative but also able of synthesizing, sciences that are ancillary to the legal sciences have been developed, which, however participate, in equal measure, in the research of the juridical phenomenon and in its practical application, namely: legal sociology, juridical ethnology, legal anthropology, legal logic, legal psychology, legal economy, legal informatics, etc., which are, as a matter of fact, interdisciplinary sciences. Consequently, law cannot remain singular in its approach, because it interferes with many other sciences and

\footnotetext{
${ }^{13}$ I. Craiovan, Exigențele Demersului Științific - Repere Majore Pentru Configurarea Ramurilor Dreptului, in Dreptul no. 3/2017, p. 24 and the following.

${ }^{14}$ J. Gardner, The Legality of Law in Associations, vol. 7, "The IVR $21^{\text {st }}$ World Congress", Lund, Sweden, 2003 , Plenary Sessions papers, p. 89-103, apud I. Craiovan, Exigențele Demersului Științific - Repere Majore Pentru Configurarea Ramurilor Dreptului, in Dreptul no. 3/2017, p. 25.

${ }^{15}$ O. Podaru, Dreptul, între fragmentare şi re(coagulare), in Dreptul no. 4/2017, pp. 10-17.
} 
creates connections, interferences, transfers of concepts, manifesting itself in diversity, from which it cannot escape and by virtue of which it oscillates between unification and specialization.

Fragmentation has gradually generated a phenomenon of absolutization of the research by approaching a complex perspective. Numerous legal institutions have been placed in real time and space, and reported to an overall view, and they successfully defined themselves and created their own rules and principles, thereby highlighting a certain branch of law and gradually claiming their title of branch of law. Such examples are: electoral law, derived from the constitutional law, environmental law, public health law, urbanism law, detached from the administrative law, maritime law, cambium law, transport law, competition law, insolvency law, detached from the commercial law. Moreover, law has crossed the traditional jurisdictions, the legal norm being "modelled" by its interaction, and its interconnection with international, union law norms, giving rise to international law, European Union law, corporate law, international arbitration, cross-border insolvency, etc. We support the doctrinal opinion according to which complex research of legal phenomena ensures the dimension of the synthesis and deepening, by overcoming the level provided by branch sciences, through the multidisciplinary and interdisciplinary approach, etc. ${ }^{16}$ Nevertheless, practitioners mention legal blockages and conflicts at the legal practice level, due to the attempt to create an allencompassing, complex and autonomous legal order in each area of application, by overlapping competences, national norms and international norms. ${ }^{17}$

The border between a branch of law and an institution can often be imperceptible, and this is a controversial topic in the specialized literature. The outlining of a new legal discipline, or even a veritable branch of the legal system, has a detailed and long-lasting course, such as, for example, that of the insolvency institution which gradually succeeds to establish itself with a new status, exceeding the status of a law institution corseted in the provisions of the Code of Commerce, with the abrogation of the latter and the entry into force of the new Civil Code, a revolutionary moment that marked the affirmation and evolution of special, peculiar rights.

Thus, in contrast to the fragmentation trend, which certainly provided the depth of the analysis, law reverted to unity, attempting a normative cohesion, with the entry into force of the new Romanian Civil Code in 2011. This tendency towards unity led to the brutal disappearance of certain branches of law, such as family law and commercial law, on the grounds that the legal norms are closely interlinked and form a whole, an organic ensemble, the unification creating an internal, functional and balanced normative coherence, based on the interdependencies between these branches of law. This scientific approach, addressing the legal phenomenon in a unitary and complex, borderless manner, of re(coagulation) according to a recent doctrinal opinion, ${ }^{18}$ has generated very many controversies, doctrinal opinions in antithesis about the survival of the branches of law, especially those of commercial law, virtually absorbed by the civil law through their "return to its origin".

Taking into account the evolution of commercial law as a distinct branch of private law, its own institutions which it created as sub-branches and which were subsequently developed as special laws, complementary laws, we believe that it is difficult to admit and recognize the effective disappearance of this law and reconsider as a part of the civil law, especially since this law has not lost its essence, being totally absorbed by the Civil Code and resized on the basis of new concepts, namely "professional" and "enterprise", concepts that obviously delimit the commercial legal relations and the civil relations.

However, we cannot deny the structural and functional dependence, the subordination of commercial law to civil law, the Commercial Code being considered before its repeal a special, incomplete law, which is supplemented by civil law and the general principles of civil

\footnotetext{
${ }^{16}$ Emil Bălan, Gabriela Varia, Fragmentare și interdisciplinaritate în cercetarea fenomenelor juridice, in Dreptul no. 4/2017, pp.18-21.

${ }^{17}$ Case Micula/Romania - http://www.mircea-asociatii.ro/sesiune-comunicari-londra-sustinuta-emanuela-matei/. ${ }^{18}$ O.Podaru, op.cit., pp. 10-17.
} 
law. Moreover, it is obvious that the commercial law has taken over, adapted and expanded civil law institutions. Civil law, as a common law, general law, is resized, expanded and adapts continuously, encompassing rules and institutions of the commercial law, through the so-called "commercialization" of the civil law. ${ }^{19}$

Paradoxically, this unification, by opening the frontiers between the aforementioned branches of law, has in fact allowed for the construction of other branches of law that have "escaped' from the branch of commercial law as simple legal institutions but which have founded their own "regulatory code", gradually claiming their special, peculiar law, pointing our attention in this analysis to the legal institution of insolvency, which certainly exceeds the civil law. ${ }^{20}$ Consequently, we are currently witnessing a new fragmentation of the law, despite the aim of legislative unification pursued by the new Civil Code, putting "under scrutiny" new forms of law derived from the classical commercial law, such as corporate law, banking law or insolvency law, the inevitable result of the transformations, changes and continuous evolutions generated in the society, law proving over time that it is able to match social realities and to ensure the required analytical deepness.

We discovered that interdisciplinary vision is not, actually, a mere cohesion that merges landmarks, information, opinions, perspectives, subjects, fields, etc., being, instead, an intersection, synthesis and remodeling of sciences in general, which cannot be separated from a historical time. Consequently, interdisciplinarity involves a multiplication of perspectives that synthesize and create, in a integrative vision, a complex final "product", as is the case of the institution of insolvency, which has gone beyond the boundaries of the traditional branches of law, by incorporating social, economic, administrative, management factors, as law displays a flexible legal dimensioning and management, adapted to the needs of the economic crisis, global conflicts and problems.

\section{INSOLVENCY - A TRANSCENDENT MATTER, WITH A UNIFYING ROLE, WHICH HAS GONE BEYOND THE BOUNDARIES ESTABLISHED BETWEEN THE TRADITIONAL BRANCHES AND SYSTEMS OF LAW}

The institution of insolvency, more specifically bankruptcy, originates from the Commercial Codes, becoming gradually detached and outlining its own legislative course through the advent of Law no. 64/1995 on the procedure of judicial reorganization and liquidation, followed by Law no. 85/2006 on the insolvency procedure, Law no. 381/2009 on the introduction of the preventive arrangement and the ad hoc mandate, with the purpose of safeguarding the debtor in difficulty through amicable procedures for the renegotiation of creditors' claims or their conditions and, finally, the drafting of an Insolvency Code, namely Law no. 85/2014 on insolvency and insolvency prevention procedures, which corresponds to a vision aimed at promoting entrepreneurship, investment and employment.

With good reason, the current law on insolvency is considered to be a veritable Insolvency Code that proposes an integrative vision, which includes in a single regulatory corpus the general legislation, applicable to all economic operators, the special legislation applicable to credit institutions and insurance companies, to groups of companies as well as regulations on cross-border insolvency, in addition to insolvency prevention instruments, the ad hoc mandate, and the preventive arrangement.

\footnotetext{
${ }^{19}$ See I. Didea, D.-M. Ilie, Insolvența - instituție de drept sub egida dreptuluicivilîn lumina teoriei moniste sau parte componentă a corolarului legislației comerciale în lumina teoriei "supraviețirii”" dreptuluicomercial? Intre tradiție și modernitate, in Curierul Judiciar no. 6/2017, pp. 320-328.

${ }^{20}$ See I. Didea, D.-M. Ilie, Un nou statut al instituției insolvenței raportat la viziunea monistă promovată de Noul Cod Civil. Conturarea unui drept special, particular - dreptul insolvenței-urmare a abrogării Codului Comercial, in Curierul Judiciar no. 8/2017, pp. 425-434.
} 
Insolvency law has undergone a remarkable evolution, becoming a legal phenomenon accessible to other legal subjects through the elaboration of Law no. 151/2015 ${ }^{21}$ on the insolvency of natural persons, as well as of Government Emergency Ordinance no. 46/2013 approved by Law no. 35/2016 $6^{22}$ on the insolvency of the administrative-territorial units, provisions that reflect and strengthen the current trends at European level and outline a new "architecture" of insolvency in the Romanian legal space as an incontestable effect of the present and future economic and social reality.

Having a brief overview of the legislative evolution related to insolvency, we can notice the accelerated legislative expansion in this field, which field has been outlined in a multitude of social, economic, and financial perspectives, thus becoming a complex system of harmonized legal norms in a fragile general context under the pressure of globalization, the domino effect of the economic crisis, unemployment, the refugee crisis, security and citizens' rights, which are the current subjects of interest in the development of strategies by the bodies of the European Union. ${ }^{23}$

Although it interferes with both domestic and international normative acts on labor law, criminal law, civil law, civil procedural law, administrative law, banking law, public procurement law, etc. and was substantiated an integrative vision of the branches related to the sphere of economy, sociology, etc., insolvency law created its own course in the attempt to achieve its objectives, being currently harmonized with the monist system implemented by the new Civil Code but also driven, at the same time, in its evolution, by the principles promoted at the level of the European Union.

In the specialized literature, we also find opinions according to which commercial law keeps its existence by outlining a new law, oscillating between the name of economic law, enterprise law, and business law. Thus, we find a tendency of multidisciplinary and interdisciplinary approach, in the attempt to resize the commercial law by outlining a new, complex law, which comprises, in addition to the norms specific to the commercial law, other legal norms established in the business field (fiscal, administrative, processual, and labor law, etc.), in this case a veritable business law, the special laws that are essentially commercial, until the repeal of the Commercial Code (including the insolvency law), being integrated into this new branch of law and creating a new legal reality. This opinion is also supported in the foreign specialized literature ${ }^{24}$ that is also supported by Romanian doctrines, and according to

\footnotetext{
${ }^{21}$ Initially, Law no. 151/2015 on insolvency procedure of natural persons, published in the Official Journal of Romania, Part I, no. 464 of 26June, 2015, should have entered into force on 26 December, 2015. The first postponement was made by Government Emergency Ordinance no. 61/2015 for 31 December 2016, followed by Government Emergency Ordinance no. 98/2016, which extended the deadline for the entry into force to 1 August, 2017, meanwhile the Methodological Norms for the application of Law no. 151/2015 were also approved. Nevertheless, the application of Law of Insolvency of Natural Persons faces a new postponement of the entry into force, namely 1 January, 2018, according to Government Emergency Ordinance no. 6/2017, published in the Official Journal of Romania no. 614 of 28 July, 2017, on the grounds of the complexity of the field regulated by this law, and also due to the point of view of the Superior Council of Magistracy who points out the fact that a rigorous preparation of the administrative capacity of the courts called to apply the natural person insolvency procedures is required. The letter of the Superior Council of Magistracy also mentions that the recently adopted law on datio in solutum and the unpredictability regulated by the Civil Code provides alternative solutions for the cases where contractual misbalances led to the loss of the utility of the contract for one of the parties. Consequently, the expansion of the deadline for the application of the Law on the procedure of insolvency of natural persons ensures the time required for the training of the staff in charge.

${ }^{22}$ Official Journal no. 219/ 24.03. 2016.

${ }^{23}$ Document de reflexion sur la maîtrise de la mondialisation, 10 May, 2017, https://ec.europa.eu/commission/publications/reflection-paper-harnessing-globalisation_fr

${ }^{24}$ In France, part of the doctrine considers that the business law includes the commercial law, the latter being a subassembly of business law. Thus, the French authors (Brigitte Hess-Fallon, Anne-Marie Simon, Droit commercial et des affaires, Paris, 1996), consider that the business law, being interdisciplinary, cannot be reduced to the norms comprised in the Commercial Code, but outside the commercial law, and includes: labour law rules, public law rules, through the intervention of the state in the economy by programmes, international
} 


\section{THE INTERDISCIPLINARITY OF THE SCIENTIFIC RESEARCH OF LAW. THE \\ INSOLVENCY INSTITUTION - AN INTEGRATIVE AREA CONFIGURED AND RESIZED \\ BY THE INTERSECTION OF THE LEGAL, ECONOMIC AND SOCIAL REALITIES}

which "commercial law is a multi-disciplinary business law, comprising both private and public law rules, and this nature is undeniable." 25

Indeed, an interdisciplinary approach, an in globo research within this corpus of business law, allows for merging perspectives from an expanded sphere, through a trans-systemic, crosssectoral research, outlining a final legal product, a complex one, multi-dimensioned to the real existence, such as that of insolvency. Nevertheless, the actual absorption by the business law of so many specific rights, which already tend towards their own evolutions and resizing, is a difficult legislative step, especially as we already have the example of the unification of the civil and commercial obligations according to the monist system, which has generated numerous doctrinal controversies, legislative interpretations, while at the same time putting in motion an entire mechanism of legislative correlation and harmonization, which can create dangers of legal insecurity.

However, we cannot deny that only by creating an open "border" framework we can find the way to understanding the complexity, processes of fragmentation followed by unification, leading to the combination of different elements to create something new, and in this case we see how the disappearance of a branch of law, respectively that of the commercial law, has led to the construction of other possible branches, as such as, for example, the insolvency law. Is the insolvency law the result of the fragmentation of the commercial law? From this point of view, we consider that, in relation to its evolutions, the institution of insolvency succeeds in becoming gradually detached as a distinctive special law in relation to the civil law, and even more so in relation to the commercial law, unlike the old bankruptcy legislation, exceeding the narrow sphere of traders, due to the fact that we are currently talking about the insolvency of professionals, the insolvency of natural persons, but also the insolvency of the administrative-territorial units with a genuinely separate normative corpus, but which could form a common corpus in the future, even approached in an integrative vision that could be the subject of a true Insolvency Code.

We notice the fact that the institution of insolvency has covered a path of knowledge from disciplinarity, to interdisciplinarity and transdisciplinarity, cultivating an integrative style and trying to exceed the boundaries of traditional disciplines, the boundaries between public law and private law, which exceeds the civil law, the commercial law through integration and intersection with the norms of public interest, with emphasis on reorganization, recovery, rehabilitation, as procedures that extend especially in the direction of safeguarding the subjects involved due to a general interest that is necessary in the current economic and social context according to the new objective of the European Commission.

Insolvency tends towards a unitary coordination and an integrative vision of these protection mechanisms that really address distinctive legal subjects, but which have the same main objective by aspiring to outline a new Insolvency Code that could facilitate the access to such procedures by eliminating regulatory overlaps, with the obvious maintenance of the specific legal regime.

Thus, although there is still a deeply rooted boundary between the public law and the private law, and the three aforementioned normative acts, which have the same regulatory object, but address subjects of law belonging to distinctive systems of law, the essence of the modern normative goals of insolvency for all the legal subjects to which it is addressed remains the identification of a balance between the interests of the debtor and those of the creditors through their constructive harmonization, which is reflected in the judicial reorganization regulated by Law no. 85/2014 on insolvency and insolvency prevention procedures, financial

conventions, criminal law rules, such as tax evasion, etc. - M. Nicolae, Unificarea dreptului obligațiilor civile și comerciale, Universul Juridic, Bucharest, 2015, pp. 623-624.

${ }^{25}$ D. Clocotici, Gh. Gheorghiu, Delimitarea actelor de drept civil faţă de actele juridice cu character comercial, in Revista de Drept Comercial no. 6/1998, p. 43-44. 
recovery according to the rules of G.E.O. no. 46/2013 regarding the financial crisis and the insolvency of the administrative-territorial units, approved by Law no. 35/2016, as well as the well-deserved fresh start granted to natural persons, as regulated by Law no. 151/2015 on the insolvency of natural persons, passing through the current economic and social filter the importance and the necessity to approach these mechanisms promoted both in the national and in the national context, but also in the union one.

\section{CONCLUSION}

Although we tend to start from the premise that interdisciplinarity is an abstract, purely theoretical, philosophical notion, we cannot deny its profound, profound mark on the society in general, due to the fact that man by nature is a complex being, living, creating, building and evolving through an overall picture, a multidimensional picture in which thoughts, information, needs and ideas are intersected, in the attempt to find perfection.

Essentially, performance in research, which actually involves the evolution of humanity, society, or even survival in such a fragile world, which faces a high degree of pollution, ecological disasters, financial, economic, political crises, disease untreatable by the development of bacteria, uncontrollable viruses, etc., obviously requires an interdisciplinary approach through a multitude of perspectives and through the incorporation of visions that belong to even completely opposed domain.

Law is a result of the multidisciplinarity, interdisciplinarity and transdisciplinarity, being an essential factor in the organization of life and society that cannot be separated from a historical time, the economic, political, cultural, organizational state of an era, being resized with the evolution of humanity.

Consequently, we need a cognitive consciousness of the complexity in any legal approach to promote an open, flexible, forward-looking law that at the same time succeeds in preserving its identity, autonomy and specificity within this dynamic process. It is not by accident that we have mentioned the institution of insolvency in this study. It is one of the institutions of law that has evolved remarkably throughout history to this day, being indeed a result, a product of the interdependence of legal, social, economic factors, which is moving towards an autonomous law, has filtered out its own principles and operating procedures. Insolvency transcends the traditional branches of law and creates a viable "resuscitation" mechanism of the economy, a survival mechanism against budget imbalances, at the center of interest of national, union and international bodies.

Based on the new vision of strong economic recovery promoted at European Union level, with a focus on outlining a legal culture oriented towards the promotion of entrepreneurship, investments, employment, in the light of the remedial, recovery and revival perspective of professionals, and of natural persons, as consumers, who also have the opportunity to develop and implement a debt repayment plan, the insolvency institution can be an instrument for the development and implementation of the strategy of the European Union - Europe $2020^{26}$, corresponding to the priorities of creating an industry, competitive economies, as well creating jobs and reducing poverty.

\section{REFERENCES:}

1. EmilBălan, Gabriela Varia, Fragmentare şi interdisciplinaritate $\hat{i n}$ cercetarea fenomenelor juridice, in Dreptul no. 4/2017;

2. D. Clocotici, Gh.Gheorghiu, Delimitarea actelor de drept civil față de actele juridice cu character comercial, in Revista de Drept Comercial no. 6/1998;

\footnotetext{
${ }^{26}$ https://publications.europa.eu/en/publication-detail/-/publication/b89e2b0b-dda7-4ea3-936c37adcf74ce27?Wt.mc_id=NEWSLETTER_october2017-interested-in-banners
} 
THE INTERDISCIPLINARITY OF THE SCIENTIFIC RESEARCH OF LAW. THE

INSOLVENCY INSTITUTION - AN INTEGRATIVE AREA CONFIGURED AND RESIZED

BY THE INTERSECTION OF THE LEGAL, ECONOMIC AND SOCIAL REALITIES

3. V. Cojanu, Interdisciplinaritatea în științele sociale ca problemă de management, in Revista de Politica Științei și Scientometrie -New series, Vol. 3, No. 1, INOE, Măgurele, 2014;

4. Craiovan, Exigențele Demersului Științific - Repere Majore Pentru Configurarea Ramurilor Dreptului, in Dreptul no. 3/2017;

5. Didea, D.-M.Ilie, Insolvența - instituție de drept sub egida dreptului civil în lumina teoriei moniste sau parte componentă a corolarului legislației comerciale în lumina teoriei "supraviețuirii" dreptului comercial? Intre tradiție și modernitate, in Curierul Judiciar no. 6/2017;

6. Didea, D.-M. Ilie, Un nou statut al instituției insolvenței raportat la viziunea monist promovată de Noul Cod Civil. Conturarea unui drept special, particular - dreptul insolvenței - urmare a abrogării Codului Comercial, in Curierul Judiciar no. 8/2017;

7. J. Gardner, The Legality of Law in Associations, vol. 7, "The IVR $21^{\text {st }}$ World Congress", Lund, Sweden, 2003, Plenary Sessions papers, apud I. Craiovan, Exigențele Demersului Științific - Repere Majore Pentru Configurarea Ramurilor Dreptului, in Dreptul no. 3/2017;

8. Casey Jones, Interdisciplinary Approach - Advantages, Disadvantages, and the Future Benefits of Interdisciplinary Studies, ESSAI, Volume 7, 2010http://dc.cod.edu/cgi/viewcontent.cgi? article $=1121 \&$ context $=$ essai

9. Jula, Interdisciplinaritatea și transdisciplinaritatea, factori de creștere a calității învățământului universitar - http://www.agir.ro/buletine/83.pdf.

10. Lisa R. Lattuca, L.J. Voight, K.Q. Fath, Does Interdisciplinarity Promote Learning? Theoretical Support and Researchable Questions, The Review of Higher Education, Fall 2004, Volume 28;

11. M. Nicolae, Unificarea dreptului obligațiilor civile și comerciale, Universul Juridic, Bucharest, 2015;

12. B. Nicolescu, "The Transdisciplinary Evolution of the University" http://cds.cern.ch/record/365269/files/SCAN-9809055.pdf

13. O. Podaru, Dreptul, intre fragmentare și re(coagulare), in Dreptul no. 4/2017;

14. Julie Thompson Klein, Interdisciplinarity: History, Theory and Practice, Wayne State University Press, Michigan, 1990;

15. Document de reflexion sur la maîtrise de la mondialisation, 10 Mai 2017, https://ec.europa.eu/commission/publications/reflection-paper-harnessingglobalisation_fr

16. OECD, Interdisciplinarity: Problems of Teaching and Research in Universities, Paris, OECD, 1972, apud C. Toth, Raport privind cercetarea interdisciplinară, DOCSOC Excelență, inovație și interdisciplinaritate în studiile doctorale și postdoctorale în sociologie

17. http://docsoc.sas.unibuc.ro/wp-content/uploads/2013/09/DOCSOC_E2_Raportcercetare-interdisciplinara.pdf

18. http://www.oecd.org/sti/inno/measuringinnovationanewperspective.htm

19. http://www.oecd.org/innovation/research/37592129.pdf

20. https://www.mae.ro/node/18539

21. http://www.mircea-asociatii.ro/sesiune-comunicari-londra-sustinuta-emanuela-mateil.

22. https://publications.europa.eu/en/publication-detail/-/publication/b89e2b0b-dda7-4ea3936c-37adcf74ce27?Wt.mc_id=NEWSLETTER_october2017-interested-in-banners 